\title{
PEMBUATAN COUNTER ELECTRODE KARBON UNTUK APLIKASI ELEKTRODA DYE-SENSITIZED SOLAR CELL (DSSC)
}

\author{
Siti Chadijah ${ }^{*}$ Dahyunir Dahlan ${ }^{*}$ Harmadi ${ }^{*}$ \\ ${ }^{*}$ Jurusan Fisika, FMIPA Universitas Andalas \\ Kampus LimauManis, Pauh, Padang 25163 \\ e-mail:csiti1612@gmail.com,dahyunir@yahoo.com
}

\begin{abstract}
ABSTRAK
Telah dilakukan pembuatan counter electrode karbon di atas substrat Indium Tin Oxide (ITO) untuk aplikasi DSSC. Counter electrode karbon dibuat dari; goresan pensil 7B, jelaga api lilin, serta kombinasi goresan pensil dangan jelaga api lilin. Komposisi bahan dasar terdiri dari serbuk karbon dari pensil, cetyl trymetil ammonium bromide (CTAB) dan $\mathrm{TiO}_{2}$. Hasil karakterisasi mikroskop optik memperlihatkan sumber karbon yang berasal dari jelaga api lilin menghasilkan morfologi permukaan sangat halus dan homogen serta terdistribusi merata pada substrat ITO. Sementara dari foto mikroskop electron (Scanning Electron Microscope, SEM) sampel tersebut memperlihatkan adanya pori-pori. Dari pengukuran karakteristik I-V dihitung efisiensi sel surya yang menggunakan elektroda karbon tersebut. Efisiensi counter electrode yang diperoleh dari goresan pensil adalah $0,064 \%$, jelaga api lilin adalah $0,163 \%$, goresan pensil dan jelaga api lilina dalah $0,088 \%$, jelaga api lilin baru digores pensil 0,008\%, campuran serbuk karbon dengan $3 \mathrm{~mL}$ air serta 0,1 gram CTAB serta 0,1 gram TiO2 $0,065 \%$.
\end{abstract}

Kata Kunci: Karbon, ITO, Counter electrode, DSSC, Efisiensi

\begin{abstract}
Have been fabricated carbon counter electrode on a substrate Indium Tin Oxide (ITO) for the application of DSSC. Counter carbon electrode made of: pencil 7B, soot a candle flame, a combination of pencil strokes invitation soot a candle flame. The composition of the base material consisting of carbon powder pencil, cetyl trymetil ammonium bromide $(\mathrm{CTAB})$ and $\mathrm{TiO}_{2}$. The results of the characterization of an optical microscope shows a carbon source derived from a candle flame produces soot surface morphology is very smooth and homogeneous and evenly distributed on the ITO substrate. While the electron microscope photograph (Scanning Electron Microscope SEM) of the sample showed pores. From the I-V characteristic measurement calculated efficiency solar cells using the carbon electrodes. Efficiency counter electrode obtained from a pencil is $0.064 \%$, soot flame is $0.163 \%$, a pencil and soot fire lilina dalah $0.088 \%$, a new candle flame soot pencil scratched $0.008 \%$, a mixture of carbon powder with $3 \mathrm{~mL}$ of water and 0.1 grams $\mathrm{CTAB}$ and 0.1 grams of $\mathrm{TiO} 20.065 \%$.
\end{abstract}

Keywords: Carbon, ITO, Counter electrode, DSSC, Efficiency

\section{PENDAHULUAN}

Energi surya merupakan sumber energi yang paling menjanjikan. Penggunaan energi surya juga tidak berdampak pada peningkatan emisi $\mathrm{CO}_{2}$. Salah satu piranti yang dapat mengubah energy surya menjadi energi listrik adalah sel surya berbasiskan dye misalnya Dye Sensitized Solar Cell, DSSC (Dahlan dkk, 2014). 
DSSC merupakan alternatif pengganti sel surya silikon yang memiliki efisiensi cukup tinggi, mudah dalam proses pembuatan serta harga yang relatif murah (Graetzel, 2003). Dominasi silicon dapat tergantikan dengan hadirnya sel surya generasi terbaru, yaitu DSSC (Barnoy dkk, 2011). Sebuah DSSC dapat berfungsi baik jika komponen-komponen penyusunnya berada pada posisi yang benar dan setiap komponen bekerja dengan optimal menurut fungsinya. Secara umum sebuah DSSC tersusun atas beberapa komponen, diantaranya foto anoda dan counter anoda. Counter electrode atau elektroda lawan juga mempengaruhi efisiensi DSSC, sehingga banyak menjadi subjek penelitian. Counter electrode berfungsi sebagai katalis dalam reaksi reduksi ion triiodida $\left(\mathrm{I}_{3}{ }^{-}\right)$menjadi ion iodida $\left(\mathrm{I}^{-}\right)$. Kecepatan reaksi reduksi pada counter electrode (katoda) penting untuk keberlangsungan proses konversi energi matahari menjadi energi listrik. Reaksi yang terjadi pada fotoanoda harus lebih lambat dari reaksi yang terjadi pada counter electrode(Shelke, dkk., 2013).

Material yang digunakan pada elektroda lawan adalah zat yang tidak mudah bereaksi (inert), seperti platina, emas dan karbon. Material karbon menjadi alternatif karena ketersediaan yang melimpah di alam serta memiliki struktur yang bervariasi, diantaranya karbon nanotube, karbon nanowire,campuran grafit hitam dengan nanokristalin $\mathrm{TiO}_{2}$. Batang grafit atau grafit lunak pada pensil juga dapat dipakai sebagai counter electrode.

Bahan yang mengandung karbon memiliki sifat yang menguntungkan seperti konduktivitas elektronik cukup tinggi (Key dan Graetzel, 1996), tahan korosi terhadap triiodida, reaktivitast inggi untuk reduksi triiodida dan biaya rendah, sehingga merupakan alternatif pengganti platinum (Key dkk., 1996; Joshi, 2009).

Dalam penelitian ini, peneliti membuat counter elektrode dari karbon, dengan beberapa model dan metode penempatan karbon pada substrat ITO, guna mendapatkan counter electrode yang dapat diaplikasikan pada DSSC.

\section{METODE PENELITIAN}

\subsection{Preparasi SubstratITO}

Tahap awal preparsi substrat ITO adalah dengan memotong substrat sehingga berukuran $(1,0 \times 0,8) \mathrm{cm}$. Selanjutnya substrat ITO dibersihkan menggunakan alat ultrasonic cleaner. Substrat ITO dimasukkan ke dalam gelas kimia yang berisi air suling (aquabides) di getarkan menggunakan ultrasonic cleaner lagi selama 15 menit. Selanjutnya air aquabides diganti dengan larutan etanol 96\%, dan substrat ITO di ultrasonic cleaner selama 15 menit. Substrat ITO selanjutnya dikeringkan dan disimpan ke kotak petri dish.

\subsection{Pendeposisian Counter Electrode Karbon pada Substrat ITO}

Pada penelitian ini dilakukan pembuatan dan pendeposisian counter electrode karbon diatas substrat ITO menggunakan beberapa perlakuan seperti yang terlihat pada Tabel 2.1 . 
Tabel 2.1: Kode sampel counter electrode karbon

\begin{tabular}{|c|c|l|}
\hline No & $\begin{array}{c}\text { Kode } \\
\text { Sampel }\end{array}$ & \multicolumn{1}{|c|}{ Pendeposisian Counter Electrode Karbon } \\
\hline 1 & A & Substrat ITO yang digores pensil 7B \\
\hline 2 & B & Substrat ITO yang dibakar pakai jelaga api lilin \\
\hline 3 & C & $\begin{array}{l}\text { Substrat ITO digores kemudia dibakar pakai } \\
\text { jelaga api lilin }\end{array}$ \\
\hline 4 & D & $\begin{array}{l}\text { Substrat ITO yang dibakar pakai jelaga api lilin, } \\
\text { kemudian digores pakai pesil }\end{array}$ \\
\hline 5 & E4 & $\begin{array}{l}\text { Larutan 0,5 gram serbuk karbon pensil yang } \\
\text { sudah diayak menggunakan pengayak, } \\
\text { ditambah } 3 \text { mL air dan 0,1 gram CTAB serta } 0,1 \\
\text { gram } \mathrm{TiO}_{2}\end{array}$ \\
\hline
\end{tabular}

Pada sampel, bagian yang akan dideposisikan counter elektrode karbon adalah bagian konduktif dari substrat ITO. Sampel E4 proses pembuatannya adalah sebagai berikut; Counter electrode karbon yang berasal dari pensil 7B, digerus dan dihaluskan menggunakan mortar. Kemudian diayak menggunakan pengayak yang ukurannya sampai $53 \mu \mathrm{m}$. Pengayakan ini dilakukan agar memperoleh serbuk karbon yang berukuran sangat halus.

Preparasi larutan karbon diawali dengan mencampurkan serbuk karbon sebanyak 0,5 gram dengan $3 \mathrm{~mL}$ air dan 0,1 gram CTAB serta 0,1 gram $\mathrm{TiO}_{2}$. Ketiga bahan ini diaduk menggunakan magnetic stirrer selama 1 jam menggunakan suhu $80{ }^{0} \mathrm{C}$, sehigga meghasilkan pasta koloid karbon. Tujuan pengadukan menggunakan magnetic stirrer pada suhu $80{ }^{\circ} \mathrm{C}$ agar larutan homogen dan kadar air yang terkandung dalam larutan berkurang. Selanjutnya pasta koloid karbon hasil sintesis dideposisikan di atas substrat ITO menggunakan metode doctor blade, dimana keempat sisi substrat ITO berukuran $(1,0 \times 0,8) \mathrm{cm}$ dipasang scotch tape. Pasta koloid karbon diletakkan pada salah satu sisi substrat ITO kemudian di doctor blade sampai menutupi daerah yang tidak ditutupi scotch tape. Partikel karbon berukuran 10-30 nm dengan ketebalan 20-60 $\mu$ m diharapkan terbentuk pada substrat ITO. Scotch tape dilepaskan dan lapisan yang sudah terbetuk dibiarkan beberapa waktu hingga kering, kemudian sampel yang telah dideposisikan diletakkan dalam crucibel dan dimasukkan ke dalam furnace untuk proses pemanasanpada temperatur $200{ }^{\circ} \mathrm{C}$ dengan waktu tahan 1 jam. Proses ini bertujuan untuk menumbuhkan kristal, meningkatkan homogenitas butir dan menguatkan gaya adhesi antar lapisan dengan substrat.Selanjutnya, lapisan yang terbentuk kemudian dikarakterisasi menggunakan mikroskop optic dan SEM

\subsection{Preparasi Dye}

Dye yang digunakan dalam penelitian ini adalah daun pandan, daun pandan dicuci dengan menggunakan air ledeng, setelah itu dibersihkan lagi menggunakan air suling, kemudian diletakkan pada sebuah tempat yang ditutupi tisu, setelah itu biarkan mengering. Daun pandan yang sudah kering digerus dengan mortal hingga halus. Sebanyak 10 gram serbuk daun pandan ditimbang dan dicampurkan dengan $50 \mathrm{~mL}$ etanol 99,99\% kemudian disimpan selama 2 jam agar pigmen dye larut dalam etanol (Zhou, dkk., 2011). Selanjutnya campuran disaring menggunakan kertas penyaring whatman, dan disimpan dalam botol gelap. Dye yang telah disaring siap digunakan sebagai sensitiser pada DSSC. 


\subsection{Preparasi Larutan Elektrolit}

Larutan elektrolit dibuat dari bahan-bahan kalium iodida (KI), dan iodin $\left(\mathrm{I}_{2}\right)$. Sebanyak 0,83 gram $(0,5 \mathrm{M})$ kalium iodida $(\mathrm{KI})$ dilarutkan ke dalam $10 \mathrm{~mL}$ Asetonitril, kemudian diaduk menggunakan magnetic stirrer, selanjutnya ditambahkan 0,127 gram $(0,05 \mathrm{M}) \mathrm{I}_{2}$ dan diaduk lagi sampai homogen selama 30 menit (Septina, dkk., 2007). Selanjutnya larutan disimpan dalam botol tertutup.

\subsection{Perakitan (Assembly) dan Pengujian DSSC}

Substrat ITO yang sudah dilapisi $\mathrm{TiO}_{2}$ direndam kedalam larutan dye pandan selama 1 jam, bagian ini sebagai fotoanoda kemudian disandwich dengan counter electrode dan dijepit dengan clipbinder agar tidak bergerak. Selajutnya larutan elektrolit ditetesi diantara sela-sela kedua substrat konduktif, sehingga larutan tersebut menyebar dan DSSC siap diuji.

\subsection{Karakterisasi Arus-Tegangan (I-V) DSSC}

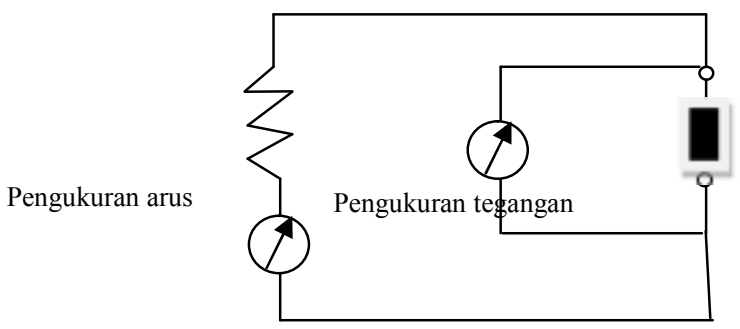

Gambar 2.1 Diagram pengukuran karakteristik I-V

Diagram metode pengukuran karakterisasi $I-V$ DSSC ditunjukkan pada Gambar 2.1. Sel yang diukur disinari oleh lampu halogen dan beban $500 \mathrm{k} \Omega$ pada sirkuit sehingga didapatkan kurva $I-V$. Efisiensi konversi cahaya Matahari menjadi energi listrik pada sebuah DSSC dapat dihitung dengan formula :

$$
\eta=\frac{P_{\max }}{P_{\text {in }}} 100 \%
$$

Di mana, $P_{m}$ merupakan nilai maksimum dari daya output $\mathrm{mWcm}^{-2}$.

$$
P_{\max }=I_{m} V_{m}=I_{s c} V_{o c} F F
$$

dengan $V_{m}$ adalah tegangan yang memberikan nilai daya maksimum, $I_{m}$ adalah arus yang memberikan nilai arus mA.cm ${ }^{-2} . P_{\text {in }}$ adalah daya masukan dari sumber cahaya yang digunakan, diukur dalam $\mathrm{mW} . \mathrm{cm}^{-2}$,

$$
F F=\frac{l_{m} V_{m}}{\left(I_{s c} V_{a c}\right)}
$$

$I_{s c}$ didefinisikan sebagai arus ketika potensial sama dengan nol (arus hubungan singkat) dalam $\mathrm{mA} . \mathrm{cm}^{-2}, V_{o c}$ adalah tegangan rangkaian terbuka (open circuit voltage), yaitu tegangan ketika beban luar yang diberikan sangat besar.

$$
\eta=\frac{l_{s c} V_{o c} F F}{P_{\text {in }}}
$$




\section{HASIL DAN DISKUSI}

Dari penelitian ini telah dilakukan, pendeposisian counter electrode karbon yang terbentuk pada substrat ITO dapat dilihat pada Gambar 3.1. Terlihat bahwa Counter electrode karbonnya berasal dari pensil 7B yang digores saja (Sampel A), hanya sedikit karbon yang dapat terdeposisi dengan baik. Hal ini disebabkan oleh permukaan kaca yang licin. Sampel B counter electrode karbonnya berasal dari jelaga api lilin. Terlihat sangat halus dan homogen serta terdistribusi secara merata pada substrat ITO. Hal ini dapat terjadi dikarenakan jelaga api lilin mampu menempel dengan baik pada substrat ITO. Sampel C, counter electrode karbonnya berasal dari goresan pensil 7B ke substrat ITO kemudian dibakar menggunakan api lilin sehingga karbon yang menempel lebih banyak bila dibandingkan dengan sampel B. Sampel D, counter electrode karbonnya berasal dari kombinasi antara jelaga api lilin dengan digoresi oleh pensil 7B, disini terlihat bahwa counter electrode tidak menempel dengan baik. Hal ini dikarenakan pada saat penggoresan terjadi pengikisan karbon yang berasal dari jelaga api lilin, sehigga hanya sedikit karbon yang mampu terdistribusi. Akibatnya counter electrode karbon ini tidak mampu bekerja dengan baik.

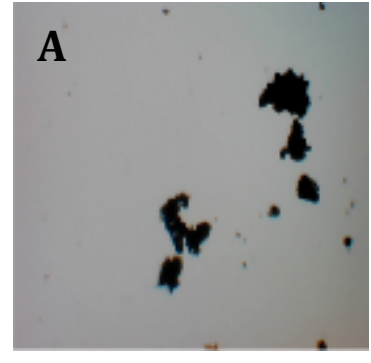

D

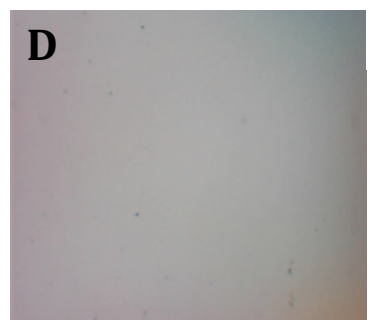

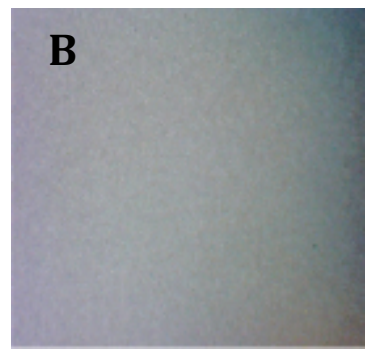
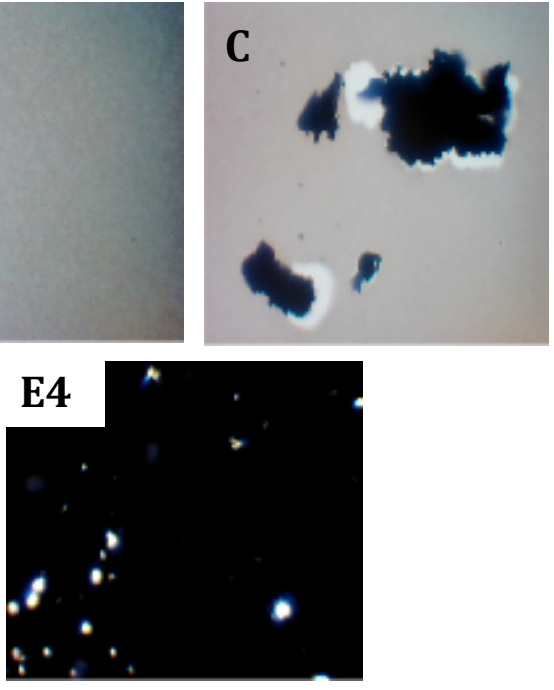

Gambar 3.1 Hasil Foto mikroskop optik permukaan sampel counter electrode karbon pada substrat ITO yang (A) digores pensil 7B, (B) jelaga api lilin, (C) digores pensil kemudian dibakar apililin, (D) dibakar kemudian digores pensil, (E4) campuran antara 0,5 gram serbuk karbon pensil $+0,1$ gram $\mathrm{CTAB}+0,1$ gramTiO $_{2}$.

Sampel E4, counter electrode karbonnya berasal dari 0,5 gram serbuk pensil 7B ditambah $3 \mathrm{~mL}$ air dan 0,1 gram $\mathrm{CTAB}$ serta 0,1 gram serbuk $\mathrm{TiO}_{2}$. Counter electrode karbonnya dapat menempel dengan baik, hal ini dikarenakan adanya CTAB. CTAB dalam larutan ini berfungsi sebagai template sehingga karbon dapat menempel lebih banyak pada substrat ITO dan CTAB juga mampu mereduksi ukuran partikel. 


\subsection{Hasil karakterisasi SEM Counter Elektrode Karbon}

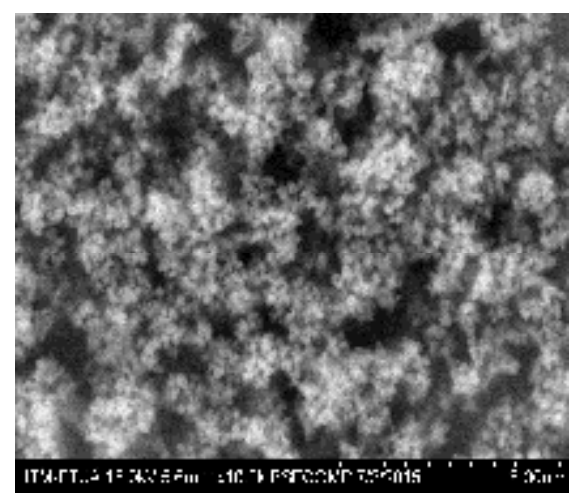

Gambar 3.2 Foto SEM lapisan karbon yang terbentuk pada substrat ITO dengan metode doctor blade pada perbesaran $10.000 \mathrm{x}$

Pada penelitian ini dipilih 1 sampel yaitu sampel E4 yang memiliki karbon cukup banyak dari hasil mikroskop optik. Hasil SEM memperlihatkan partikel karbon mampu terdistribusi dengan baik. Karbon mampu terdistribusi dengan baik atas bantuan beberapa surfaktan yaitu CTAB dan $\mathrm{TiO}_{2}$. Penambahan $\mathrm{CTAB}$ membuat karbon terdistribusi lebih merata karna fungsi CTAB sebagai template dalam larutan ini. Sementara $\mathrm{TiO}_{2}$ membuat partikel lebih halus yang menyebabkan terbentuknya pori -pori yang lebih kecil. Poripori inilah yang nantinya berfugsi sebagai area sentuh elektrolit untuk mereduksi ion triodida $\left(I_{3}^{-}\right)$menjadi ion ionida $(I)$. Ukuran partikel yang terbentuk adalah 500 nanometer.

\subsection{Analisis Grafik Arus-Tegangan (I-V)}

Hasil peforma DSSC yang dibuat ditampilkan pada Tabel 3.2. Pada perhitungan efisiensi DSSC, kuat arus yang diperoleh dikonversikan ke dalam rapat arus $(J)$ dalam $\mathrm{mA} / \mathrm{cm}^{2}, J$ $=I .1000 /$ A, dengan $I$ adalah arus yang terukur pada alat solar simulator, $A$ merupakan luas daerah DSSC yang disinari berbentuk persegi panjang maka luasnya adalah $(1,0 \mathrm{x}$ $0,8)=0,8 \mathrm{~cm}^{2}$.

Tabel 3.2 Parameter peforma DSSC counter electrode Karbon

\begin{tabular}{|c|l|c|c|c|c|}
\hline No & \multicolumn{1}{|c|}{ Jenis Preparasi karbon } & $\begin{array}{c}\text { Kode } \\
\text { Sampel }\end{array}$ & $\mathbf{V}_{\mathbf{o c}}(\mathbf{m V})$ & $\mathbf{I}_{\mathbf{s c}}(\mathbf{m A )}$ & $\begin{array}{l}\mathbf{J}_{\text {sc }} \\
\left(\mathbf{m A} / \mathbf{c m}^{2}\right)\end{array}$ \\
\hline 1 & $\begin{array}{l}\text { Karbon pensil 7B yang digores ke } \\
\text { substrat ITO }\end{array}$ & Sampel A & 513 & 0,002 & 0,0025 \\
\hline 2 & Substrat ITO yang dipanaskan saja & Sampel B & 511 & 0,006 & 0,0075 \\
\hline 3 & $\begin{array}{l}\text { Substrat ITO yang digores pensil } \\
\text { kemudian dipanaskan }\end{array}$ & Sampel C & 445 & 0,004 & 0,005 \\
\hline 4 & $\begin{array}{l}\text { Substrat ITO yang dipanaskan baru } \\
\text { digores dengan pensil }\end{array}$ & Sampel D & 410 & 0,002 & 0,0025 \\
\hline 5 & $\begin{array}{l}\text { 0,5 gram serbuk karbon pensil } \\
\text { dengan 3 mL air dan 0,1 gram } \\
\text { CTAB serta 0,1 gram TiO } 2 .\end{array}$ & $\begin{array}{c}\text { Sampel } \\
\text { E4 }\end{array}$ & 448 & 0,005 & 0,00625 \\
\hline
\end{tabular}

Dari Tabel 3.2 dapat dijelaskan bahwa DSSC dengan sumber karbon dibakar saja memperoleh kuat arus short circuit dan rapat arus short circuit lebih besar bila 
dibandingkan dengan sampel yang lainnya. Hal ini menunjukkan sumber karbon yang berasal dari jelaga api lilin, baik digunakan sebagai counter electrode pada DSSC.

Untuk sampel A nilai $V_{o c}$ nya lebih besar bila dibandingkan sampel B namun $I_{s c}$ yang dihasilkan pada sampel B lebih kecil dari sampel B. Hal ini dikarenakan sedikitnya karbon yang terdistribusi dengan baik pada substrat ITO akibatnya luas permukaan karbon yang terdistribusi juga kecil sehingga mempengaruhi jumlah arus yang dihasilkan untuk elektroda kerja. Fungsi utama dari counter elektrode adalah untuk mempercepat kinetika reaksi proses reduksi ion triiodida $\left(I_{3}^{-}\right)$menjadi ion iodida $(I)$. Permukaan karbon yang luas sangat mempengaruhi kerja dari counter electrode itu sendiri.

Untuk sampel C dan sampel D merupakan kombinasi sumber karbon antara jelaga api lilin dengan pensil namun yang membedakannya disini adalah proses penempatannya. Hasil yang diperoleh juga berbeda, untuk sampel C dengan nilai $V_{o c} 445 \mathrm{mV}$ dan $I_{s c} 0,004$ $\mathrm{mA}$ lebih besar jika dibandingkan dengan sampel D yaitu $V_{o c} 410 \mathrm{mV}$ dan $I_{s c} 0,002 \mathrm{~mA}$, semua ini dikarenakan sampel $\mathrm{C}$ jumlah karbon yang terdistribusi lebih besar bila dibandingkan dengan sampel D sehingga mempengaruhi jumlah arus yang dihasilkan untuk elektroda kerja.

Sampel E4 dengan tambahan surfaktan, nilai $V_{o c} 448 \mathrm{mV}$ dan $I_{s c} 0,005 \mathrm{~mA}$ jauh lebih baik bila dibandingkan sampel $\mathrm{A}$, sampel $\mathrm{C}$, dan sampel $\mathrm{D}$ meskipun sumber karbonnya sama yaitu serbuk pensil, semua ini merupakan akibat dari jumlah karbon yang mampu terdistribusi pada counter electrode. Selanjutnya karakterisasi I-V DSSC counter electrode karbon dapat dilihat padaT abel 3.3.

Tabel 3.3 Karakterisasi $I-V$ DSSC counter electrode karbon

\begin{tabular}{|c|c|c|c|c|}
\hline No & Sampel & $\boldsymbol{F F}$ & $\mathbf{P}_{\max }(\mathbf{w a t t})$ & $\boldsymbol{\eta ( \% )}$ \\
\hline 1 & $\mathrm{~A}$ & 0,266 & $2,31 \times 10^{-7}$ & 0,064 \\
\hline 2 & $\mathrm{~B}$ & 0,193 & $5,92 \times 10^{-7}$ & 0,163 \\
\hline 3 & $\mathrm{C}$ & 0,181 & $3,22 \times 10^{-7}$ & 0,088 \\
\hline 4 & $\mathrm{D}$ & 0,038 & $3,09 \times 10^{-8}$ & 0,008 \\
\hline 5 & $\mathrm{E} 4$ & 0,106 & $2,37 \times 10^{-7}$ & 0,065 \\
\hline
\end{tabular}

Pada Tabel 3.3 terlihat karakterisasi I-V DSSC counter electrode karbon. Jika ditinjau dari $P_{\max }$ yang dihasilkan oleh kelima sampel, sampel B yang memiliki daya paling besar. Hal tersebut disebabkan karena arus dan tegangan yang dihasilkan juga besar. Nilai $F F$ pada hasil karakterisasi $I-V$ DSSC counter electrode karbon, terlihat pada Tabel 3.3. Sampel yang memiliki nilai $F F$ tertinggi adalah sampel A yaitu 0,226 . Besarnya hasil yang diperoleh masih jauh dari hasil yang diharapkan yaitu 1 (kondisi ideal). Nilai efisiensi $\eta$ yang dihasilkan kelima sampel tersebut yang memiliki efisiensi tertinggi terdapat pada sampel B yaitu sebesar $0,163 \%$ dan sampel yang nilai $\eta$ paling kecil adalah sampel D sebesar $0,008 \%$.

Hasil karakterisasi $I-V$ kelima sampel DSSC counter electrode karbon dapat dilihat pada Gambar 3.3.PadaGambar 3.3dapatdijelaskan bahwa $I-V$ pada sampel B menghasilkan nilai tertinggi bila dibandingkan keempat sampel lainnya. Hal tersebut menunjukkan bahwa counter electrode karbon yang berasal dari substrat ITO yang dipanaskan saja dapat digunakan dalam aplikasi DSSC. Untuk sampel C kombinasi antara karbon yang 
berasal dari pensil dan jelaga api lilin baik untuk dijadikan sebagai counter electrode. Hal ini dapat terlihat dari Gambar 3.3.Diikuti oleh sampel E4 yaitu kombinasi karbon yg berasal dari serbuk pensil dengan penambahan surfaktan CTAB dan $\mathrm{TiO}_{2}$ juga mampu menghasilkan arus dan tegangan pada DSSC. Sedangkan untuk sampel A, pensil yang digores ke substrat ITO belum mampu menghasilkan counter electrode yang baik untuk aplikasi DSSC. Hal ini disebabkan karena karbon tidak mampu menempel secara baik pada substrat ITO. Sampel D sumber karbon yang berasal dari kombinasi jelaga api lilin kemudian digores pensil juga belum menghasilkan counter elctrode yang baik bila dibandingkan dengan keempat sampel yang lainnya. Hal ini dikarenakan pada saat penggoresan sumber karbon yang berasal dari jelaga api lilin terkikis, hanya sedikit karbon yang mampu menempel. Akibatnya $I-V$ yang dihasilkan juga kecil jika dibandingkan pada keempat sampel.

Semakin banyak karbon yang mampu menempel pada substrat ITO, maka semakin luas area sentuh counter elektrode dengan larutan elektrolit, akibatnya karakterisasi $I-V$ dan efisiensi yang dihasilkan juga akan baik.

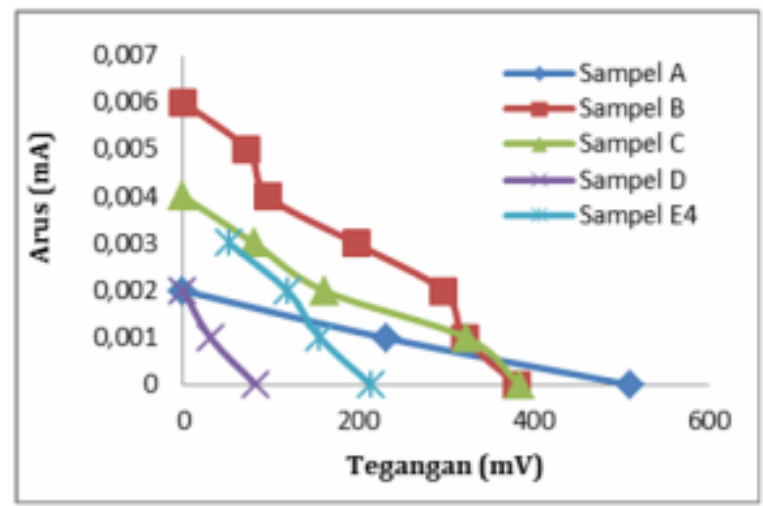

Gambar 3.3 Hasil karakterisasi $I-V$ kelima sampel dari DSSC counter electrode karbon

\section{KESIMPULAN}

Pada penelitian ini telah berhasil dilakukan pendeposisian karbon pada substrat ITO sebagai counter electrode. Lapisan counter electrode karbon dengan efisiensi tertinggi terdapat pada substrat ITO yang disintesis menggunakan jelaga api lilin. Efisiensi tertinggi dihasilkan pada DSSC yang menggunakan lapisan counter electrode karbon yang berasal dari jelaga api lilin sebesar $0,163 \%$. Diikuti oleh karbon yang digores kemudian dibakar dengan api lilin sebesar 0,088\%.

\section{DAFTAR PUSTAKA}

1. Barnoy, E., Conley, M., Gan, S., Gafe, Y., Lovell, J., Mann, K., Shuchatowitz, A., Tobin, C., 2011, The Potential of Natural, Photosynthetic Pigments To Improve the Efficiency of Dye-Sensitized Solar Cells, PhD Thesis, University of Maryland, Maryland.

2. Cahen, David., 2004, Review Articles: Physical Chemical Principles of Photovoltaic Conversion with Nanoparticulate, Vol.108, Mesoporous DSSC. J. P. Chem. B 
3. Dahlan, D. dan Fahyuan, H., 2014, Pengaruh beberapa jenis dye organik terhadap efisiensi sel surya dye-sensitized solar cell, Jurnal Sains Material Indonesia, Vol. 15, No.2, pp. 74-79.

4. Gratzel, M., 2003,'Dye-sensitized solar cells, Journal of Photochemistry and Photobiology C: Photochemistry Reviews, Vol. 4, pp. 145-153.

5. Joshi. P., 2009. ,'Dye-sensitized solar cell based on low cost nanoscale Carbon/TiO 2 composite counter electrode. Energy \& Environmental science 2, pp.426-429.

6. Kay. A and Graetzel. M., 1996, Low Cost Photovoltaic Modules Based On Dye Sensitized Nanocrystalline Titanium Dioxide and Carbon Powder, Solar Energy Materials and Solar Cells, Vol. 44, no. 1, pp. 99-117.

7. Lee, K.M., Suryanarayanan, V., Ho, K.C., 2006, The Influence of surface morphology of TiO2 coating on the perform/hui ance of dye-sensitized solar cell, Solar Energy Materials \& Solar Cell, Vol. 90, pp. 2398-2404.

8. Lia, M., Natalita, M, N., 2012. DyeSensitized Solar Cells Based on Carbon Nanoparticle Counter Electrode. Research Center for Electronics and Telecommunication, Volume 35, Number 1-6, LIPI Bandung.

9. Lungu, L., Stefan, N., Prodana, G., Georgescua, A., Mandes, A., Ciupina. V., Mihailescus, I. N., Girtua, M. A., 2015, Characterization of Spin Coated TiO2 Buffer Layers for Dye Sensitized Solar Cell, Digest Journal of Nanomaterials and Biostructures, Vol. 10, No. 3, pp. 967-976.

10. Septina, W., Fajarisandi, D., Aditia, M. 2007. Pembuatan Solar Cell Murah dengan Bahan-bahan Organik-Inorganik. Laporan Penelitian Bidang Energi, ITB: Bandung

11. Shao, L., Chen, M., Ren, T., Yuan, Z., 2014. Ordered Mesoporous Carbon/Graphene Nano-Sheets Composites as Counter Elctrodes In DyeSensitized Solar Cell. Journal of power sources 274, 791-789.

12. Suzuki, K., Yamaguchi, M., Kumagai, M., 2003, Application of Carbon Nanotube to Counter Electrodes of Dye-Sensitized Solar Cell, Chem. Lett. Vol, 32 , pp. 28-29, 2003.

13. Wang, G., Wang, D., Kuang, S., Xing, W., Zhou, S., 2014, Hierarchical porous carbon derived from rice husk as a low-cost counter electrode of dye-sensitized solar cell, Journal School of Chemical Engineering Shandong University of Techology, Vol. 63, pp. 708-714. 